\title{
Exploring School Leaders' (SLs) Perspectives and Understanding about Globalization and Its Effects on Their Leadership Practices in District Ghizar, Gilgit-Baltistan, Pakistan
}

\author{
Abdul Wali Khan, Gulzar Afaqi \\ Institute for Educational Development (IED), Aga Khan University, Karachi, Pakistan \\ Email: abdulwali.abdali@gmail.com, Gulzar.afaqi.med14@gmail.com
}

How to cite this paper: Khan, A. W., \& Afaqi, G. (2019). Exploring School Leaders' (SLs) Perspectives and Understanding about Globalization and Its Effects on Their Leadership Practices in District Ghizar, Gilgit-Baltistan, Pakistan. Creative Education, 10, 1037-1061.

https://doi.org/10.4236/ce.2019.105078

Received: March 27, 2019

Accepted: May 27, 2019

Published: May 30, 2019

Copyright $\odot 2019$ by author(s) and Scientific Research Publishing Inc. This work is licensed under the Creative Commons Attribution International License (CC BY 4.0).

http://creativecommons.org/licenses/by/4.0/

\begin{abstract}
Regardless of interpretations and explanations, globalization has direct bearing with education, educational leadership practices and classroom instructions. This study explored school leaders' perspectives about the effects/impacts of globalization on leadership practices and school culture as a whole in a mountainous district (Ghizer) of Gilgit-Baltistan, Pakistan. Theoretically grounded in globalization and educational leadership, the study was methodologically landed on qualitative phenomenological case study. Data were collected from 8 schools principals (4 public and 4 private) using an eclectic set of tools: semi-structured interviews, focused group discussion (FGD) and field notes. The findings showed that globalization has affected not only school leaders' leadership practices, but has also facilitated the reshaping of schools' culture, students' learning, teachers' teaching, educational policies and the role of community in the education of their children. The study highlighted both the positives and negative effects of globalization: in one hand it has created competition among learners, has reshaped educational policies, made information accessible, and has changed students' style of learning, their language, food and clothing, while also bringing drastic change in teachers' pedagogy. On the other hand it has had serious consequences for local and indigenous culture. The study confirms that no matter whether the schools' leaders are prepared for the change, it has to occur. It is recommended that school leaders need to be proactive and develop certain literacies such as social, moral, academic and democratic in order to better cope with the pressing demands associated with globalization.
\end{abstract}




\section{Keywords}

Globalization, Leadership, Educational Practices, School Leaders, Policies

\section{Introduction and Background to the Study}

Globalization is an evolving and complicated concept with numerous interpretations and theoretical underpinning that seem hard to operationalize. Nonetheless, a contested explanation and interpretation of globalization normally reads that it is a many-sided ideological and politically charged process and generally is an overarching umbrella term to explicate the intricate sequence of economical, political, social and technological changes where ideas, opinions, money services and goods, people and business are moved from local and national to the international realm. Consequently, there is likelihood of increasing the interdependences and interconnectedness among people, cultures, ethnic groups, government entities and organizations from different geography to a large global arena (Steiner-Khamsi \& Waldo, 2012). Held, McGrew, Goldblatt, and Perraton (1999) define globalization as "a process [ or set of processes] which embodies a transformation in the spatial organization of social relations and transactions assessed in terms of their intensity, velocity and impact-generating transcontinental or interregional flows and networks of activity, interaction, and the exercise of power" (p. 16).

Globalization influences education because what to teach, learn, test and study has direct bearing with globalization particularly in developing countries like Pakistan. Scholars speculate mixed understanding about globalization. Proponents acclaim its advantages as a medium of linking and accelerating understanding and learning surrounded by a world community, while opponents warn and predict for social, intellectual and cultural colonization and potential co-modification (Darling-Hamond \& Lieberman, 2012). Brooks and Normore, (2010) opine that with the economic growth in globalization, globalization of knowledge also rises, which blurs the boundaries of knowledge that used to be discrete and local or national systems of education.

Education in Pakistan is underway of restructuring as a result of globalization and neoliberal reforms. These educational reforms in addition to other areas heavily influence the role of educational leaders in policy formation, their status as leaders and the characteristics the SLs should possess in order to understand and cope with the emerging educational needs of $21^{\text {st }}$ century classroom and its management (Tarar, 2006).

\section{Effect/Impact of Globalization on Educational Leaders}

As discussed above, regardless of the explanation and interpretation of globalization, its effects are obvious in every walk of our lives. This ranges from drinking and eating to dressing and driving among general "worldwide activities" 
(Mulford, 2008). Cognizant of these facts, therefore, it is important for educational leaders to be able to accurately sense global forces and pressures, and try to adjust and cope with the competitive changes that will inevitably be thrust upon them, and eventually distinguish that globalization is a complex and multifaceted process. Moreover, it is also important for school leaders to be aware of the diverse forms of globalization (economical, social, language and technological) that happen and to consider several dimensions to frame their functions and prepare themselves to absorb the leadership challenges in the future. Researchers emphasize the study of various dimensions of globalization; Tikly (2010) and Burden-Leahy (2009) urge the study of economic, political and social aspects to provide a vivid picture of specific contexts. Berger (2007), Bottery (2006) and Held \& McGrew (2007) on the other hand emphasize the study of demographic, technological, linguistic, and environmental dimensions in order to provide a more comprehensive description and interpretation of the ways in which globalization is specifically impacting and altering the role of educational leaders in the early 21st century. Given this situation, what is happening in Pakistan generally and in Gilgit-Baltistan specifically, the impact/effects of globalization are unknown. Therefore, understanding the voices and perspective of SLs from Gilgit-Baltistan becomes important in understanding how it is perceived, and how globalization has caused/facilitated the shaping and reshaping of their practices and what challenges they face. These questions are critical to ask and explore in order to foster students' learning and for wider dissemination in order to make scholars, educators, policy makers and other stakeholders knowledgeable about the topic. In addition, globalization has extensively been explored in the sphere of industry and economy. However, globalization is still uncharted and an under-explored area in the education field. This is due partly because of the prevailing perception that globalization is an abstract idea which has no straight connections with the daily work of schooling and practices that leadership perform, and also due to a fixation on more immediate and local imperatives (Jungck \& Kajornsin 2003). The question then arises of what characteristics should a school leaders possess in the globalized $21^{\text {st }}$ century? And how does globalization influence the practices and perceptions of educational leaders? Many educational leaders confess that diverse concepts and pressing issues related to globalization influence their local practices such as school management, classroom and assessment instructions and feedback, planning and staff development (Apple, Kenway, \& Singh, 2005). Indeed, as Spring (2008) explains, "research on globalization and education involves the study of intertwined worldwide discourses, processes, and institutions affecting local educational practices and policies" ( $\mathrm{p}$. 320).

Keeping these facts in view, this study aimed to unearth the perspectives and perceptions of school leaders on how globalization has facilitated and reshaped leadership practices of decision making, policy formulation and assessment. Another aim was to highlight the impacts of globalization on teachers' pedagogy, students' learning, and the role of community to education, which has direct 
bearing with student learning. Local insights are a valuable addition to the ongoing discussion of globalization and informed documents for policy makers, educational managers and all those who are directly or indirectly related to the field of education.

\subsection{Theoretical Position}

This study focused on exploring perspectives and practices of school leaders about the effects of globalization on leadership practices. Therefore, theoretically the study is grounded in theories of leadership and globalization. Familiarity with the theory provided a base for the study on what has already been in the academia and what needs to be done further and what were the gaps in the existing body of literature. The study under discussion brought local insights to fill the gap and also added value to the ongoing discussion on globalization and its impacts on leadership practices in schools.

Predominately, there are eight theories of globalization which have reached a general consensus among researchers. These theories include; liberalism, political realism, marxism, constructivism, postmodernism, feminism, transformationalism and eclecticism. Constructivism has the most relevance to the topics explored in this study and as such will be discussed in the following sections.

\subsection{Theory of Constructivism}

Constructivists argue that globalization occurs because people construct their social world with certain symbols, language, images and interpretations. Also, dynamics and forms of consciousness result in globalization (Appadurai, 1996). Constructivists further claim the governance and pattern of production is deeply rooted in and emanates from cultural and socio-psychological forces. The central argument in constructivism is that people/social actors construct and co-construct their ideas by social interaction, experiences, communication and dialogue with each other. Moreover, exchange of ideas/experiences can allow people/individuals to construct ideas of their own world, formulate rules for livings and belonging in that world. This interpretation of globalization has stemmed from fields such as anthropology, humanities and sociology where social geography is a mental experience and physical fact (Creswell, 2007; Glaser, 2007; Merriam, 2009; Glesne, 2013). In addition, according to Appadurai (1996) constructivists consider that:

They are the inhabitants of a particular global world. National, class, religious and other identities respond in part to material conditions but they also depend on inter-subjective construction and communication of shared self-understanding. However, when they go too far, they present a case of social-psychological reductionism, ignoring the significance of economic and ecological forces in shaping mental experience. This theory neglects issues of structural inequalities and power hierarchies in social relations. It has a built-in apolitical tendency.

As mentioned above, since the study focused on understanding and inquiring school leaders' perspectives and leadership practices as an effect/impact of glo- 
balization, it also falls under leadership theory, particularly participatory and democratic leadership. The history of leadership is as long as human history and is even prevalent in animals and birds (Gronn, 2010; Casimir et al., 2013; Lingard \& Christie, 2003). Review of leadership history reveals that early leadership was mostly concentrated with what makes a leader unique from the followers while the later idea places emphasis on what the factors that make a successful leader are (Casimir et al., 2013). According to Casimir et al. (2013), Hudson (2013) and Gronn, (2010) the $20^{\text {th }}$ century witnessed the emergence of four leadership theories such as (1) "Trait Theory" or the "Great Man Theory". This theory speculates that leaders are born with innate qualities and traits of intelligence, visions and ideas and these leaders are different from average people. Thus, it is presumed that a leader is a person with certain qualities, visions and skills. (2) Behaviorist theory posits that leaders are not born but made though training, education, exposure and training. In other word, individuals have innate potential to become a leader if they develop certain skills and behavior. Similarly, situational leadership theory emphasizes that one size doesn't fit all. If a leader is effective and successful in one situation, the leader may not be success in another situation or context (Hudson, 2013; Greenleaf, 1977). In any given situation, a successful leader is one who makes decisions according to the situation and context and applies the style of leadership which best suits the situation. The last leadership theory is participatory leadership theory which assumes that no matter how knowledgeable and skillful a leader may be, without support and expert opinions from colleagues change will not occur. This leadership theory has generated other leadership concepts such as democratic leadership, consultative leadership, distributed and shared leadership among others (Bush \& Glover, 2014; Harris, 2004). According to Lewin (1939) this theory describes three kinds of leadership. These include autocratic leadership where the leader takes on solo decision-making powers and does not include the suggestions and opinions of other staff members. As a result other members can become disgruntled and revolt. For instance, if a school principal is an autocratic leader, he/she may not only deprive the school of benefiting from the ideas, views and wisdom of other school community members such as teachers, students, and parents, but he/she may also face resistance in implementing his decisions. Quite opposite to this is a democratic leader who not only involves and takes input from everyone in making a decision but also creates a culture of collaboration, collegiality, team work, and a greater sense of mutual respect and shared understanding. A principal employing this style of leadership may not only encourage teachers, students, staff and parents to have a voice in, and contribute to effective management of the school but he/she may also be able to turn the school into a learning community (Khaki, 2010; Harris,2004). Similarly, Laissez-faire leadership facilitates members of the school community in making their own decisions and solving their own problems (Tajik, 2010).

There are certainly both strengths and some limitations attached to these leadership theories and styles and these are subject to further investigation and 
evolution. Therefore, other theories of leadership have emerged in different disciplines. Thus it can be considered that each theory of leadership is emergent, dynamic, and subject to further investigation and evolution (Hudson, 2013; Santamaría, 2016).

Although the concept of leadership can be found throughout human history, it has been not so long ago that a number of educational and school leadership theories emerged (Bogotch, 2011; Covey, 1992; Sergiovanni, 1992). Drawn largely from commerce and business management principles, the theories of educational/school leadership have been adopted and adapted for use in educational settings around the globe. According to Santamaría (2016), "the theories of educational leadership have been derived from a diversity of interdisciplinary conceptualizations and models over time" (p. 1). An analysis of these theories reveals the characteristics (traits and behaviors), styles, practices and conceptual frameworks of leadership. Some of the contemporary theories and styles of educational leadership include; instructional leadership, learning-centered leadership, managerial leadership, transformational leadership, distributed leadership, situational leadership, ethical leadership, and pedagogical leadership (Bush \& Glover, 2014; Male \& Palaiologou, 2012; Bogotch, 2011; Brundrett, 2011; Leithwood \& Jantzi, 2011; Starratt, 2004; Casimir et al., 2013; Harris, 2004; Glatter \& Kydd, 2003).

Pedagogical leadership is essentially the study of teaching and learning processes, understanding how learning takes place and the philosophy and practice that support the understanding of learning. In other words, it focuses more on knowledge creation and management than knowledge transmission (Male \& $\mathrm{Pa}$ laiogou, 2012). For knowledge generation, it is important that teachers, students and other members of school community are empowered to actively participate in all academic activities and decisions about the school's management. Thus, pedagogical leadership can be considered as an alternative leadership style to provide an effective learning environment in which students feel empowered, trusted and valued. According to Sergiovanni (1992) pedagogical leadership "develops human capital by helping schools become caring, focused, and inquiring communities within which teachers [and others] work together as members of community of practice" (p.37) for improving student learning outcomes.

Alameen et al. (2015) argue that pedagogical leadership is not just supporting teaching and learning but it is a "praxis" that "is concerned with theory, practice and a set of social axes" (p. 8). These authors further argue that there is no one best way of leading or practicing leadership but leadership action and practice should be appropriate to the particular situation and social context in which it is applied. Consequently, pedagogical leadership becomes an ethical approach, which respects socio-cultural values and benefits the ecology of a community rather than benefiting an individual. School principals employing pedagogical leadership styles focus on involving teachers, students, parents and others in the day-to-day business of their schools in order to turn the schools into learning 
communities (Tajik, 2010). They treat teachers, students and other members of school community as people who are capable of making valuable contributions to the teaching, learning and management processes at their schools (Khaki, 2010; Shafa, 2010; Tajik, 2010; Male \& Palaiogou, 2012). However, how globalization has affected school leaders' leadership styles and what kind of leadership the SL employ to effectively run their schools, as well as how a particular leadership works for the SL in a mountainous district of Pakistan are worthy of further exploration. Hence, this study makes an important contribution to the current understanding about how globalization has shaped and reshaped the school leaders' leadership practices in order to smoothly run schools by making them a conducive learning environment for students.

\section{Methodological Context}

Against the backdrop of the above theoretical positioning, a phenomenological case study was designed to understand the perspectives, lived experiences and perceptions that SLs hold about globalization and the practices they perform in order to cope with the pressing demands of globalization. Studying schools' leaders' perspectives and practices is an acknowledgment of the centrality of human lived experience as the source of perspectives, beliefs, and assumptions. Also, they are critical to understand what is working and what is not, to modifying and improving teaching, learning and leadership practices, and to improving programmes to become more meaningful and relevant (Tajik, 2010). Eight school principals both from public and private schools were the primary participants who shared their understanding, experiences and perspectives. In addition, as a secondary source five teachers were interviewed and two focused group discussions were held with the students for richer and deeper data collection.

The nature of research question could best be answered through exploration and listening to the voices, experience, perspectives, beliefs and understandings of the educational leaders in Pakistan. Also, globalization itself is a human endeavor and therefore, employing a phenomenological case study was deemed appropriate for exploring participants' experiences, interactions, believes they have and the practices they utilize as result of their experiences. In this way they co-construct their beliefs and experiences and generate knowledge. In addition, case studies are about the thick and rich description of a social phenomenon (globalization in this study) with its unique boundary (perspectives about globalization and practices of leadership), time and space (District Ghizer of GB) (Yin, 2006). Using a number of eclectic tools such as semi-structured interviews, focused group discussion, field notes and shadowing, the data was collected from 10 principals and teachers. The participants selected were 4 principals from private schools and 4 from private sector who render their services in Ishkoman and Phander tehsils of the district. These participants were selected using purposive sampling because they were having more than two decades experiences and had lived experiences of school leadership and practices. Similarly, the teachers had also rich experiences. Operation of multiple tools helped in the triangulation 
of data.

The following research question guided the study:

What are the perceptions/perspectives of school leaders (SLs) about globalization and how have it affected/facilitated the shaping and reshaping of their leadership practices?

\section{Findings}

We discuss the findings mainly around five major themes: 1) the perceptions and perspectives of school leaders about globalization followed by 2) its effects on school leaders' leadership practices and school culture, 3) teachers' teaching and students' learning 4) effects of globalization on educational policies and 5) role of community in education in the globalized era.

Following the earlier discussion on findings/themes it is pertinent to discuss the context of the study in order to understand the geographical and social aspects of district Ghizer where the study was conducted in eight schools.

Ghizer District is the westernmost part of the Gilgit-Baltistan region of Pakistan. Its capital is Gahkuch. Ghizer is at a crossroads between Gilgit and Chitral, and also to China and Tajikistan via the Karambar Pass through Ishkomen/DarkutYasin (which are connected via Shandur Pass). Ghizer is a multi-ethnic district and three major languages (Shina, Khowar \& Brushaski) are spoken. There are some Wakhi and Tajik speakers in Ishkoman (History of Gilgit, 2017). According to ${ }^{1}$ AlifAilaan Pakistan District Education Rankings 2015, Ghizer is ranks 52 out of 148 districts in terms of education. The district ranks 71 out of 148 for facilities and infrastructure. Government is major education provider in district Ghizer with 21 high, 27 Middle and 67 Primary schools, collectively accessing 18464 students across district (DDE Ghizer Report, 2019). ${ }^{2}$ Aga Khan Education Service, Pakistan (AKES, P) stands in a district with 10 high 20 middle and 40 primary schools. Moreover, AKES, $\mathrm{P}$ also provides financial and academic support to more than 10 community schools. Overall, quality of education in Ghizer district is good compared to the other districts of GB. In the era of globalization school leaders (Public \& Private) have embraced challenges of school management (high competition and expectations, students' learning and teacher' performance). School leaders struggle to retune and refuel themselves and compete with those challenges with globalization. In the discussion below the voices, perspectives and practices of participants (the school leaders and teachers) of both systems are briefly discussed.

\subsection{Globalization for School Leaders: Local Perspectives}

The school leaders presented polarized views about globalization. For some SLs,

${ }^{1}$ Alif Ailaan is a not for profit NGO aims to promote education in Pakistan. For further reading about AlifAilaan please visit https://www.alifailaan.pk/.

${ }^{2} \mathrm{AKES}, \mathrm{P}$ is part of AKDN network and provides education services in Pakistan and many other countries. For details please refer to

https://www.akdn.org/our-agencies/aga-khan-education-services. 
globalizations is being cautious and responsive of new happenings in the fields of technology and science, keeping a close eye on those various changes and reorienting themselves to better perform in school. A participant articulated:

Globalization in the context of education has brought about many changes for the leaders; they need to be acquainted and abreast with the modern methods of teaching as well as new styles of leadership. At the same time the leader has to keep an eye on what is happening in education field nationally and globally, and how the leader can cope with the challenges or adapt the new happenings in order to better facilitate learning and also to compete with others (Interview 4, School Head: September 19, 2018).

While some SLs perceive globalization as a change in pedagogy and shift of teaching from teacher-centered to student-centered teaching, a participant explained:

Now the teachers have switched from teacher centeredness to child centeredness teaching. During observation I see children working in groups and pairs and making presentations. The teachers just facilitate them facilitate them. I would not just claim that there is a big change but however, there is an evolution that is happening in the school because of globalization. Jungck and Kajornsin (2003) in their study call such changes "pedagogical literacy" which is very important to the SL to develop in the changing globalized world (Int: 1, School Head: September 9, 2018).

Some SLs perceive globalization as advancement in technology, communication and social and economic interconnection of people. Explaining globalization a participant argued:

It [Globalization] is a new terminology, nowadays people are connected to each other, by the electronic media, print media as a means of fast communication. We cannot keep something limited to our own self. Information is open now on face book, twitters and TV. Technology has connected us to the libraries and schools around the world. We can get what we desire to learn from other countries, from other people. So, globalization has changed the scenario of the world in terms of exchanging knowledge (Int: 3, School Head: September 19, 2018).

In sum, globalization for school leaders is being cautious of the emerging trends and preparation to acquaint to it; an advanced development in technology and a shift in teaching and learning. Therefore, school leaders have to change themselves to cope with the changing world.

\subsection{Effects/Pros and Cons of Globalization}

Fast flow of and easy access to information: School leaders understood that globalization has led to a number of changes (positives and negatives) in teaching, beyond teaching, learning and the leadership practices of school leaders. Exam- 
ples include; fast flow of and easy access to information, teaching and learning resources, multimedia, soft board and Google browsing in schools to name a few. Whatever information the SLs need to know or want to share with the students or teachers is a click away.

Teaching and leadership practices, that teachers and head teachers perform in one part of the globe reaches to the other part of the world soon. Therefore, good practices are adopted/adapted or owned. Participants viewed that: "Today education is dynamic not stagnant". Teachers and students accept the positive aspect influx of information and ideas emerging in the world due to globalization.

The SLs agreed that because of the advancement in technology, schools have access to information and other teaching materials which were previously rare. Emergence of new technology requires the SLs to be skillful on this. For instance, a participant explained:

I see a drastic change in education. Earlier there were no facilities of information technology, no multi-media, no internet, and no any system of information technology. Now we have new technology available and if we face any difficulty while teaching, Google is there to help us. Similarly, we are more connected to the world so fast that the development and information which once used to reach us over 25+ years, now it reaches to us very soon and we implement it for our good (Int: Interview 2, School Head: September 12, 2018).

\subsection{Students in Globalized Era and Teachers' Professional Survival}

Use of and access to technology has changed the mindset of students because they are connected to the world via different means of communication; they watch TV, listen to the audiovisual types programs, use Facebook, and Twitter. As a result students enhance their knowledge. Therefore, it has repercussions for teachers' professional life. Hence, the teachers need to refuel and retune themselves with updated knowledge; otherwise their professional survival is at risk.

\section{Changes in Teachers, Teaching and Learning}

\subsection{Shift from Teacher-Centered to Child-Centered Teaching}

The SLs also agreed that they see a drastic change in teachers' teaching; teachers are well versed in content and pedagogy and there is a shift in teaching from teacher-centered to a child-centered. The modern teachers try to adopt other countries method of teaching and keep improving their teaching strategies. Visiting the classrooms, the SLs observe children working in groups, in pairs, and giving presentations. The teachers only guide and facilitate them. However, the public sector SL acknowledged that they do not claim that there is a big change 
but there is evolution that happens in the schools.

\subsection{Teachers' Qualification (Present and Past)}

With the passage of time, demand of qualified teachers has increased to teach students of the modern world. In earlier times matriculate would easily get teaching jobs but now only master's degree holders with professional qualifications get recruited, illustrating a large change in teachers' induction. Comparing past procedures of teachers' recruitment a teacher said, "Gradually, people with higher qualifications are inducted in the organization; initially, only matriculate or sometimes FA or BA were appointed. However this pattern exists no more. When I joined the organization having BA and PTC while the other teachers had less qualification (Martric or FA), now the minimum qualification for becoming a teacher is BEd and Master".

\subsection{Child as Receiver of Knowledge vs Child as Captain of Learning}

There was agreement among the SLs that they have witnessed various changes in the teaching learning process over the time. They view that in early 1980s teachers were considered the center of knowledge, and the pupil would come to them, greet them with respect and quench their thrust of knowledge. Nobody could dare to speak in front of the teacher and whatever the teacher could write was full and final for the students, and the students would blindly follow it. Teachers used only one method of talk and chalk. The conception is changed now. Students confidently question teacher's pedagogy, methodology and all other behavior the teacher portrays while teaching. In addition, students enjoy the centrality of teaching and they are considered captain of their own learning. The principals give this credit to globalization.

\subsection{Effects of Globalization on Students' Learning and Holistic Development}

Advancement in technology and communication has affected students' behavior, learning, life styles, perspectives and understanding. New reforms and innovation have emerged in schools. Using and engaging with those devices (TV, Computers, Internet and other teaching aids), students have boosted up their confidences and also their life style. For example, students watch Indian dramas and film which was rare in earlier times. Exposure to both electronic and print media has greatly affected their way of talking, eating, behavior with family members, teachers and colleagues. For example, students address their parents with mamma, daddy, pita etc. instead of using their local dialect or mother tongue. A participant told that: when we reflect on their behavior, we can see change in their language which is totally different e.g. they watch Hindi film, therefore, use Hindi words while speaking without noticing our own norms and the norms of others. But at the same time it has given them confidence as the 
other participant put:

In our time, we could not express our idea in front of people. We were reluctant. We could hardly say few words before the teachers. Today's child expresses his/her ideas easily. In our time, our attitude with teachers, parents and elders was very positive. We were talking very politely. We had the curiosity to understand everything. Comparatively, today's child is reactive. $\mathrm{He} / \mathrm{she}$ never tries to distinguish between the right and wrong. They insisted to do whatever they want to do (Int: 2, School Head: September 12, 2018).

\subsection{The Changing World Whether You Change or Not}

The SLs were of the view that change cannot be predicted and controlled; it has its own dynamics and way to occur. One may change and prepare for the upcoming changes and challenges the change will produce. If so happens it will sweep away the unprepared. Therefore, is important to be ready for change ahead of time.

\subsection{Positive and Negative Effects of Technology on Students}

According to the SLs globalization has caused both positive as well as negative changes in students. The positive include access to information through gadgets, saving of times, improvement in language and many mores while the negatives include, adaptation of other culture, style, language and food, developing negativity. A participant elucidated that:

If we see the positive aspect of mobile, the teachers and students have learnt a lot of information from mobile. It has eased our life and if you have smart phone, you can consult it during teaching. It takes no time for you to search vocabulary in dictionary. In earlier time, we consulted dictionary for words meaning which was time consuming. Smart phones have saved our time. Nowadays children watch dramas, comedies, and films on TV, which improves their language skills. Contrary to this there are negative aspects also. For example, the children much absorb into it and certain programs attract students toward negative thinking. The students sleep late and getup very late which is medically not good practice for health. However, if we do not maintain ourselves, the pressure of time is increasing. Now, being a school leader, it is our moral duty to divert the students' attention towards positive aspects. We need to guide our children and we need to delete negative aspects (Int: Interview 1, School Head: September 9, 2018).

\subsection{Adaptation of Western Culture}

The participants agree that whether school leaders, teachers or students we immediately adopt western culture, their style of hair and clothing, food and language. For instance, the students address their parents with "mamma" and "Da- 
dy" which they have learnt from TV. Similarly, watching Indian dramas and films they act and sing like the actor and actress in the film or drama. This shows that in one hand it is a sign of learning new knowledge and language but on the other hand it's a threat to the local and indigenous culture and language.

In the view of the school leaders globalization has had positive and negative impacts on students. The positive aspects include opportunities for learning and participation in exhibition held in down country which is a platform to interact with. Students are more informed and they raise their voices if something wrong happens to their teaching or anything else. Also, students become confident compared to the earlier students. Comparing the students of both times a participant narrated that, "We could not talk in front of elders. As an illiterate person if father did anything wrong we could not stop him. Unlike this, today's children can easily ask the parents from doing wrong things".

While the negative aspect includes the waste of time engaging with useless activities and adopting anti-culture and anti-social habits, moreover, in earlier times, teachers enjoyed full respect and now the children know that punishment is prohibited in school. So, if any child is given punishment, he/she is ready to call the police.

\subsection{Changes in SLs Leadership Practices}

The participants presented polarized views on observation and feedback. The private sector school principals understand that they have seen an evolution in some of their teachers. It is because they observe their lessons using certain observational tools. One principal told: "We go to classrooms and observe teachers' lessons. I mainly focus on finding out their strengths first and also note areas for improvement. Post observation we sit together, discuss it further and set future targets". While the public school principals admitted that they do not properly observe the teachers but instead pay seldom visits to the classes to see the teaching. Based on the visit, they write the annual confidential report (ACR) of the teachers.

In sum globalization has caused a change in leadership practices of assessment and feedback, teachers' teaching and students' learning.

\subsection{Changes in Teachers' Pedagogy/Teaching}

The SLs acknowledged that new concepts and ideas of education have been introduced in contemporary education systems which were not available in past. A participant made a comparison of his time of education and the present day of education:

When I compare my student life with today's world, there was no concept of ECD at that time. Findings of different studies and even science have proved that $90 \%$ education completes from conception to age 6 . The remaining $10 \%$ continues throughout the life. A child learns through observation. Similarly, infrastructure, communication technology, library, print 
media, and electronic media are the other changes that we see. At that time the teachers used only book for teaching and dictated the concept followed by writing the concept on the black board. The present teachers use many reference books to supplement the textbook. The teachers also take help from technology, internet and TV for preparing lessons. The technology is also useful for students as an alternative of teacher. In future the child may not need classroom teaching, there might be online schools. It is a big difference. Our homework strategy is also changed. Our practices are changed (Int: 5 Head Teacher: September 20, 2018).

Stated briefly, globalization has caused changes both positive and negative in all aspects of leadership practices, and in fast spread of information connecting people to each other. As a result there is a change in students learning and behavior. The students become more tilted towards western culture and their learning and life style is changed. This drastic change is a challenge for unprepared teachers, who once occupied on teacher-centered teaching and perceive students as passive receiver of knowledge. Consequently, teachers have updated their qualifications, refueled themselves with modern demands and shifted their teaching to more activity based placing student at the center of learning. School leaders as a whole have also changed their leadership practice in running the school business.

\section{How Do SLs Respond to Globalization?}

Similarity in understanding established among the SLs that globalization has mounted huge responsibilities on school leaders in order to cope with pressing educational demands. Previously they did not have enough burden regarding their role and practices. In the past SLs used to be dictators, powerful, above accountability for students learning and school operations and supervision. There was just a tradition to come to the school, sit on the chair like a boss and pass order, considering the teachers as oppressed and subordinate. Quite opposite to this, the present leadership is more democratic, participative, responsible and accountable. It is worthy of mention that a majority of the principals who practiced autocratic leadership in the past have been transformed in term of dealing with staff members, shouldering responsibilities, compliance of policies and procedures, having robust participation of community in the school functioning and much more. The changes in their leadership practices can be explained as influenced impacts of globalisation or exposure to various training and professional development sessions that have refueled and retuned them to do so. Comparing the leadership style of today and the past a participant eluded:

The leadership approach was dictatorship at that time. The head teachers were less qualified to support the teachers in lesson planning, developing scheme of work, and teaching methodology. The teachers didn't give individual attention. Even the teachers made students domestic chores for favor in exam. [In addition], there was no control system from director or educa- 
tion ministry. [The school head] was all in all. His subjugation was in the entire region and controlled everyone. He was not answerable to anyone. [In contrary] today's head is answerable from three sides; 1 ) is answerable to the students about the result and is answerable to the community; 2) the principal is answerable to village Education Committee (VEC), 3) answerable to higher authority. These three areas boost up his/her leadership skills. So, he/she come out of dictatorship and become leader. They empower the staff with them. We reflect in our school, everyone has a responsibility; everyone is leader in one area. He/she consider him/herself as a leader in that very area (Interview 6 FGI: September 26, 2018).

Another participant augmented:

The practices of head teacher in the past were appropriate according to the context of that time. The head teacher was leading as a boss and gives preference to status quo. The head teacher was giving order without keeping the privacy of the teachers. He believed on do or die. However, today head teachers work as a leader. Furthermore, the head teachers were not observing academic deeply. Today, you can see emerging system of assessment where students are observed very deeply. Early education system was emphasizing on cramming, so the same things were focused by head teacher. Therefore, we had to teach to the children through cramming. Moreover, the head teacher was unaware about conceptual understanding. But at that time parents involvement was not given any importance. Today, we cannot progress without parents in education. So, we work with parents, students and school committee and ensure (Interview 6 FGD: September 26, 2018).

\subsection{Sinking vs Inspiring Schools}

The SLs understood that school development is deeply rooted in the leadership of the principal. Sink or swim whatever the label the school receives, is directly linked to the school principal. In addition, school leaders were reluctance in previous generations; head teachers were ignorant about their responsibilities. Due consideration to develop the school was lacking amongst the SLs. The SLs further maintained that when school heads remained unaware about their responsibilities, the school sinks at once. Now the school head leads (particularly in private sector) as role model engaging in various planning and assignments e.g. school development plans, organizing extra classes for students for premier institutions, conducting professional sessions for the teacher and doing personal studies. The teachers also follow head teachers and put their effort in the development of the school. Similarly this travels down to the students also. All these changes have been possible due to globalization. A participant captured the whole story in the following words:

This has happened because the time demands it and there is a pressure from the management. Otherwise the head teachers might have dealt with 
few guest, and wasted the time. He might not have interacted with the teachers and also the teachers use their own way to deal with the students. Today, there is awareness till grassroots level. The students also know the importance of time, and also the teachers are aware (Int: 3, School Head, September 10, 2018).

Unlike the private schools' practices, the SLs of public schools indicated towards a locally prevailing myth about government jobs. Some participants mentioned that in public schools the principals are reluctant to bring about changes in their practices and so is the case with some teachers as well. The teachers do not want to come out of their comfort zones, believing that government jobs are like hot spring water that never stops and no one can fire them from the service. The myth is so grown that there is lack of interest for professional development of public school principals. The principals focus more on administrative task rather than academic resilience. A principal told us that now they are old aged and waiting for their retirement. The times have changed new teachers have been recruited and they should work hard (FGD: September 26, 2018).

\subsection{Academic and Administrative Roles of School Leadership: Least vs High Preferred}

The school leaders understood that earlier head teachers were less educated and overburdened. They took regular classes like other teachers as well as manage the official correspondence. Conversely, present head teachers spend more time in managerial work and do not teach in classrooms. The head teachers in present times deal with community better compared to the past. There used to be fights with communities for not understanding each other's perspectives. The SLs further endorsed that both the academic and administration are important parts of their school management and neither one can be given priority over the other. A principal narrated his role as follow:

I work in two major domains (administrations and academic). As an administrator my role is "Drawing and Disbursing Officer" (DDO) which requires me to supervise seven other school in terms of providing financial assistance as allocated in our budget by Gilgit-Baltistan government. Apart from that the major chunk is academic support; we give priority to the academic development of students. Therefore, I work with students, parents, and teachers. We conduct in house sessions for teachers in our schools to further sharpen and enhance their pedagogy and methodology and also to change their perceptions about the evolution of teaching. Thus we prepare and acquaint them with the methods and content of their teaching practices (Int: 4 September 26, 2018).

Long and short term planning: Considering the educational demands of the contemporary era, the SLs prepare strategic planning both for long and short duration. For example, school development plan (SDP) is a long-term plan of 3 to 5 years while Annual School Improvement Plan (ASIP) is a specific one year 
plan. In other words the long term plans are further breakdown and annual targets are set to reach to the ultimate goals.

Head teacher as a chameleon: one head different caps. School head is a designated and important position in running school activities smoothly. The head teachers have to take on multiple tasks. Such as to command the overall activities in the school, to make sure students' learning, parents' participation in students' learning, and community involvement are up to par, in addition to and dealing with teachers and other officials. As a professional the school head has to play his/her role both as a leader and as a manager. Also, the school head is a watchman under one umbrella and takes care of everyone who is associated with the school. A person narrated the school leader role as:

The head teachers work as an umbrella in the organization, dealing with all major and minor matters. However, the most important thing is public dealing because the head teacher has to deal with a wider community. The next stake holders are the teachers, and head teachers have to monitor their performance. Then head teacher has to see financial matter, which is observed daily and monthly basis. They have to keep balance between academics and finance. The head teacher also analyzes the result and develops remedial plans for improvement, sharing students' results with parents, sending quarterly progress reports.

\subsection{Situational Leadership}

Interestingly, we found an agreement among the SLs for being situational leader in order to better cope with the demands caused by globalization. They perceive that making a decision considering the situation and context surrounding the particular issue is very important. No matter how serious the issues are, the SLs should robustly engage stakeholders, take their opinions and see the issues from different angles, perspectives to reaches to a decision that well fits in the context and the situation. This style of leadership according to the SLs supports the stakeholders' and teachers' self-respect, motivation and improvement in performance. However, we found polarized opinions from the teachers. For instance, they view that major decisions are centrally taken both in public and private schools. Even principals have little or no participation there.

\subsection{Equality, Justice and Accountability}

The head teachers keep an eye on the environment provided to the students. $\mathrm{He} / \mathrm{she}$ tries to ensure an environment that is conducive for students' rights and is beyond the organizations' expectations. Therefore, the head teacher includes such activities which cater organization policies, students' rights, and employees' needs. He also conveys up-to-date information; so that the employee could give better services.

In the globalized era, accountability is at the heart of school policies. SLs reached annual targets and non-compliance of the policy has consequences. Therefore, school heads closely work with the teachers to achieve academic target. For instance, a participant explained about the academic target that: 
"Nowadays, the head teacher ensures accountability of the teachers' result, as the teachers are given targets in those areas where improvement is needed and monitor their progress by taking follow up. Also they are given feedback and support for further progress" (Interview 2, September 18, 2018).

Summing up globalization has facilitated change in the leadership styles of school leaders. The SLs have transformed from autocratic to democratic and owes credit for both achievements and weaknesses. The SLs unlike in the past believe in justice and equality, focus on academic rather than administrative roles and above all, under one umbrella perform various roles such as connecting with parents, students, teachers and senior management.

\section{Challenges for School Leaders in the Globalized Era}

The participants understood that emergence of new teaching methodologies and integration of technology in teaching have created a competitive environment that on one hand illustrates a paradigm shift for students learning and on the other hand has caused serious challenges for the SLs. For example, first there is a tough competition to become a school principal. In previous times a primary or middle school pass person could easily get job and gradually rose to the position of school leadership. This practice was observed more in public schools and less in private schools. The SLs acknowledged that in earlier times the public did not demand for quality; their only demand was literacy. Parents today demand quality. They do not question matter on how high the fee is? The only question they raise is if their children get quality education. This is how pressing demands comes from parents. Hence the school leaders have to do lots of work. All the times the school leader is occupied by the school's work. Thankfully, globalization has provided alternatives to ease school leaders' jobs. However, adjusting with the technology and demands are challenges for senior school leaders.

\subsection{Leadership Is Not to Give up}

The SLs perceive that one of the traits of the leadership is being persistence. A leader does not give up due to challenges. Challenges, hurdles, and barriers should not stop one to implement one's strategies or planning. A participant below explained his challenges and the way he counters said challenges:

I work with the parents as well. I find out need improvement areas and develop plans accordingly. I like to work as role model for government education system because we have mass education system. Our feeding unit is Asumber. Majority students in secondary level come from Assumber. Their parents live in the pasture areas in the summer and become disconnected from the children for the whole season. For the survival of their livelihood, the parents become close to animals and prefer domestic work over the education of their children. On my visit to primary school Assumber, I take students result with me and hold a meeting with their parents. This is how I engage them in the learning of their children. However, they need a lot of sensitization. There is a need for more 
struggles and a lot of work to get them motivated and to streamline them. So, challenges are there but I don't give up (Int: 7 September 20, 2018).

In brief nature of work, parents demand for quality of education and connecting to large community/parents in remote villages are the challenges for SLs, but the school leaders put their continued efforts without losing hopes.

\subsection{Parents and Parenting in Globalization}

School leaders argued that globalization has not only reached the students but parents also have experienced changes. Consequently, the parents' role in and approach to education has drastically been changed. For instance, Parents are well aware of the competition and challenges that globalization has created. Compare to the earlier times, the parents today are well aware of dealing with and realizing the need of students. There is a change in parents' behavior regarding education and their children. Cognizant of this fact, school leaders also effectively and robustly engage parents in the day-to-day functioning of the school in order to prepare and facilitate the students for better learning. During the FGD a teacher mentioned that "head teacher's approach to community engagement is far better nowadays. Whether its construction of school building, sharing of students results or any other issues related to school, the head teacher consults with the community" (Int: 5 August, 16 2018).

Put differently, in the globalized era school leaders no matter how democratic, talented and skillful they may be, cannot handle the school single handedly, therefore, participation and awareness of parents as key stakeholders for the educative process are important. The study of Brooks and Normore (2010) reveals that the school leaders should develop participatory literacy in order to develop collegiality and collaborative culture in the school for the larger learning interest of the students and staff empowerment.

\section{Effects of Globalization on Educational Policies}

The SLs understood that globalization has facilitated the reshaping of education policies and practices. There are more demands of orienting education toward the new knowledge economy. Consequently educational policies are being changed and new policies are made in line with the new trends and demands of the global economy. According to the participants, policies serve as forecasting measure where the policymakers foresee upcoming situations and factors and make policies accordingly. In addition, policies set the direction of what to do and limit the organization of what not to do. Therefore, several factors should be considered before formulating polices. A participant expressed his feeling this way:

To develop the polices for an organization, the policy makers need to see multiple factors for the establishment, stability, and further progress of an organization. The policies also give directions and set limits to perform an activity. For others policy is always value laden as the participant argued:

The laws are developed by keeping the culture, context and values of an or- 
ganization. Furthermore, they are up dated and changes with the passage of time to address the need of time. While some assume policy as a check and balance, a participant put this: Laws are developed for check and balance in the organization. They also inform the organization about its progress. Others view that policy makes us ready to go along the world and if we do not go with the world around us we will be left behind.

An effect of globalization was core debate amongst the participants. A majority of participants agreed that supranational or international powers influence change in local policies. Therefore, policies developed in the west/global north for their economic or political and social supremacy are transferred to the global south for making allies and gain societal benefits. To translate the idea they use funded projects as a tool to transfer policies. The participants expressed that currently government of Pakistan has launched a US funded project which aims to improve the reading culture in primary schools. The only problem with such project is the sustainability; once the projects reach its completion it can create further problems rather than resolving the current ones. However, for now the participants are happy about the projects, as one participant expressed:

Developing countries particularly Pakistan is under the burden of huge debt. Given the fact, and little spend of government GDP on education, $\mathrm{Pa}-$ kistan heavy relies on donation and aid from European Union, America, and other developed countries and international NGOs such as $\mathrm{CIDA}^{3}$ and $\mathrm{USAID}^{4}$ and other international funding agencies. Involvement of donors creates a niche for imposition of external ideas/policies as well. For instance, Pakistan Reading Project ${ }^{5}$ (PRP) operates in governments' school aiming to improve Urdu reading skills of grade 1 and 2. Being Pakistani teachers, Urdu is our national language but we are not ready how to teach Urdu to our children. So USAID introduced PRP to fill this gap. I think PRP is one of the successful models in our schools but not an ideal one. Students' reading and phonetics have improved satisfactorily (Int: 8 August 19, 2018).

\section{Discussion}

A close look on the findings reveals that the school leaders present diverging/polarized ideas about globalization. Collectively, in either way, the school leaders perceive globalization a new paradigm or demand oriented process which by connecting the world and reducing the boundaries has caused many new opportunities for school leaders. As a result there is a competition of losing and wining. In doing so school leaders' role, leadership practices, students

${ }^{3}$ CIDA refers to Canadian International Development Agency.

${ }^{4}$ United State Agency for International Development (USAID), detail can be found here: https://www.usaid.gov/.

${ }^{5} \mathrm{PRP}$ is US funded USAID project in Pakistan aims to promote reading culture in grade 1-2 students. Details on PRP here: http://www.pakreading.org.pk/. 
learning, teachers teaching, role of community and educational policies have changed which the school leaders live by.

School leaders perceived that unlike past their role as a leader has changed. There is a transition from autocratic leadership to a more participatory and democratic leadership to cope with the changing demands. Insight from the literature suggest that change is time and resource hungry and therefore it has been learnt that top-down approach did not work and that school leaders need new knowledge and skills to implement change in their schools and classrooms (Fullan, 1996).

It is clear from the perspectives of the school leaders that nature of teaching and learning is also changed. Students enjoy being the center of learning, have full freedom to question and raise their voice. Students' centrality of teaching and innovation in teaching strategies, teachers' role and responsibilities have been changed. Teachers focus their teaching on activity based and more opportunities for students to learn. In doing so, the teachers participate in professional development sessions to prepare themselves for better teaching. There are opportunities for them to grow professionally. Study of Dobre (2013) also support this idea that personal growth is also important to people, as self-actualization and the need for achievement and growth are very powerful needs that influence the development of effective organizations.

School leaders highlighted that their roles as a leader has changed because of fast flow of information and students' exposition to various programmes on TV and Internet. Despite the fact that advanced in technology has many benefits for the students but at the same times students abruptly adopt to the western culture which is threat to the indigenous culture. The study of (2012) shows that many changes have to work against the established beliefs, norms, values and practices in schools and attract students' motivation toward the new way of life which is quite opposite to their own.

Changes in students' learning style and behavior have also changed teachers teaching and leaders' leadership. The school leaders have transformed from autocratic leadership to more participatory and democratic leadership and give space to students and teachers in running the daily business of the school. Similarly, teachers have updated their qualification and give students priority while teaching. This shift in literature is related to the perspective where schools are considered sites of ideological struggle and contestation, where the values of the marketplace are cultivated, nurtured, and reinforced. There are ideological tensions clearly at work in the educational debates related to affirmative action, and student and teacher assessment. Generally speaking, however, these issues are hotly debated without serious attention given to their direct connection to economic restructuring, the dismantling of the middle class, the increasing polarization of wealth, and the subsequent racialization of populations (Peter Lang, 2011).

As major stakeholder of education, parents' role is paramount important. Un- 
like the past parents are more aware of the realization about the changes happening around them and particularly in schools and educational settings. Comparatively they are more inclined towards their children' education in the globalized era. Research studies across globe acknowledge the positive effects of parents on students learning e.g. improve reading, composition and cognitive power and overall learning achievements of the students (Epstein, 2011). However, the study also indicated that there are still issues in parents' involvement. With the passage of time, parents would realize and play their due role to the cause of education.

\section{Conclusion}

This study tried to answer the research question satisfactorily and made it confirmed that globalization has heavy existence in the mountainous rural district and confirm that globalization has large affected the school leaders practices and understanding. Numerous changes have occurred as a result of advancement in technology which has created a competitive environment that demands students, teachers, school leaders and community to be proactive in their responsibilities and also to equip them to cope with the competition. Due to globalization, the nature of work, and work load and leadership style of the school leaders have been changed. The school leaders are now credited for both making and breaking the school. Similarly, teachers' pedagogy and teaching have also been changed. There is a shift from very traditional to a robust participatory and dialogical approach is used by the teachers. However, this process is slightly less in the public schools due to lack of technological facilities.

Students being the centre of teaching have also been affected. There is a great change in their behavior, life style, learning, language, food and clothing. These changes have serious repercussions for the school leaders to reorient their leadership practices and pedagogy in order to fulfill the emerging needs and demands of the students. If so this would satisfy their learning and ultimately leading towards making a peaceful society. More importantly, change has to occur in way whether someone is ready to accept/cope or compete it. Being proactive is crucial otherwise there is survival risk professionally.

Educational policies are being made revamped and revised keeping in view the emerging needs of the market economy and hence school leaders' expositions to and awareness of those policies are important for providing effective leadership to the schools. This study confirms the complexities of globalization and leadership awareness of those complexities. Therefore, it's desirable for the school leaders to be aware of the changes happening around them. There are losers and winners of globalization; if the school leaders are proactive, their teachers, the students and the community as a whole will benefit from those technological advancements; otherwise, tides of globalization will sweep them away together.

\section{Conflicts of Interest}

The authors declare no conflicts of interest regarding the publication of this paper. 


\section{References}

Alameen, L. et al. (2015). Exploring Pedagogical Leadership in Early Years Education in Saudi Arabia. School Leadership \& Management, 35, 121-139. https://doi.org/10.1080/13632434.2014.992773

Appadurai, A. (1996). Modernity Al Large: Cultural Dimensions of Globalization. Minneapolis, MN: University of Minnesota Press.

Apple, M. W., Kenway, J., \& Singh, M. (2005). Globalizing Education. London: Peter Lang.

Berger, K. S. (2007). Update on Bullying at School: Science Forgotten? Developmental Review, 27, 90-126. https://doi.org/10.1016/j.dr.2006.08.002

Bogotch, I. E. (2011). The State of the Art: Leadership Training and Development-US Perspectives-Above and beyond Recorded History. School Leadership \& Management, 31, 123-138. https://doi.org/10.1080/13632434.2011.560662

Bottery, M. (2006). Educational Leaders in a Globalising World: A New Set of Priorities? School Leadership \& Management, 26, 5-22. https://doi.org/10.1080/13634230500492822

Brooks, J. S., \& Normore, A. H. (2010). Educational Leadership and Globalization: Literacy for a Glocal Perspective. Educational Policy, 24, 52-82. https://doi.org/10.1177/0895904809354070

Brundrett, M. (2011). Davies, B. and Davies, B. J. (2011) Talent Management in Education, London: Sage, in Education 3-13. International Journal of Primary, Elementary and Early Years Education, 39, 561-562. (Review Article) https://doi.org/10.1080/03004279.2011.564589

Burden-Leahy, S. M. (2009). Globalisation and Education in the Postcolonial world: The Conundrum of the Higher Education System of the United Arab Emirates. Comparative Education, 45, 525-544. https://doi.org/10.1080/03050060903391578

Bush, T., \& Glover, D. (2014). School Leadership Models: What Do We Know? School Leadership and Management, 34, 1-19. https://doi.org/10.1080/13632434.2014.928680

Casimir, A., Nkechinyere, O., Ugwu, R., \& Okpara, M. (2013). Philosophical Expositions of Leadership and Human Values in Catholic Social Teachings: Resolving Nigeria's Leadership Deficit and Underdevelopment. Open Journal of Philosophy, 3, 391-400. https://doi.org/10.4236/ojpp.2013.33059

Covey, S. R. (1992). Principle Centered Leadership. New York: Free Press.

Creswell, J. W. (2007). Qualitative Inquiry \& Research Design. London: SAGE Publication.

Darling-Hamond, L., \& Lieberman, A. (2012). Teacher Education around the World Changing Policies and Practices. London: Routledge, Taylor and Francis. https://doi.org/10.4324/9780203817551

Dobre, O.-I. (2013). Employee Motivation and Organizational Performance. Review of Applied Socio-Economic Research, 5, 53-61.

Epstein, J. L. (2011). School, Family, and Community Partnerships: Preparing Educators and Improving Schools (2nd ed.). Philadelphia, PA: Westview Press.

Fullan, M. (1996). Professional Culture and Educational Change. School Psychology Review, 25, 496-500.

Glaser, B. G. (2007). Theoretical Elaboration of Quantitative Data. The Grounded Theory Review, 6, 1-38.

http://groundedtheoryreview.com/wp-content/uploads/2012/06/GT-Review-vol6-no3. 
pdf

Glatter, R., \& Kydd, L. (2003). "Best Practice” in Educational Leadership and Management: Can We Identify It and Learn from It? Educational Management Administration and Leadership, 31, 231-243. https://doi.org/10.1177/0263211X030313002

Glesne, C. (2013). Becoming Qualitative Researchers: An Introduction (4th ed.). Boston: Pearson/Allyn \& Bacon.

Glesne, C. (2013). Becoming Qualitative Researchers: An Introduction. Burlington: Pearson.

Greenleaf, R. K. (1977). Servant Leadership: A Journey into the Nature of Legitimate Power and Greatness. New York: Paulist Press.

Gronn, P. (2010) Distributed Properties: A New Architecture for Leadership. Educational Management and Administration, 28, 317-338.

https://doi.org/10.1177/0263211X000283006

Gronn, P. (2010). Leadership: Its Genealogy, Configuration and Trajectory. Journal of Educational Administration and History, 42, 405-435. https://doi.org/10.1080/00220620.2010.492959

Harris, A. (2004). Distributed Leadership and School Improvement: Leading or Misleading? Educational Management Administration \& Leadership, 32, 11-24. https://doi.org/10.1177/1741143204039297

Held, D., \& McGrew, A. (2007). Globalization/Anti-Globalization: Beyond the Great Divide. Cambridge: Polity Press.

Held, D., McGrew, A. G., Goldblatt, D., \& Perraton, J. (1999). Contents and Introduction in Global Transformations: Politics, Economics and Culture (pp. 1-31). Stanford, CA: Stanford University Press.

https://www.geog.mcgill.ca/documents/Held\%20et\%20al\%201999.PDF

Hudson, P. (2013). What Makes School Leaders Inspirational and How Does This Relate to Mentoring? Open Journal of Leadership, 2, 87-94.

https://doi.org/10.4236/ojl.2013.24014

Jungck, S., \& Kajornsin, B. (2003). “Thai Wisdom” and Glocalization. In K. M. Anderson-Levitt (Ed.), Local Meanings, Global Schooling: Anthropology and World Culture Theory (pp. 27-49). New York: Palgrave Macmillan. https://doi.org/10.1057/9781403980359_2

Khaki, J. A. (2010). Effective School Leadership Practices: Case Studies from Pakistan. In J. A. Khaki, \& Q. Safdar (Eds.), Educational Leadership in Pakistan: Ideals and Realities (pp. 104-126). Karachi: Oxford University Press.

Leithwood, K., \& Jantzi, D. (2011). Transformational School Leadership Effects: A Replication. School Effectiveness and School Improvement, 10, 451-479.

https://doi.org/10.1076/sesi.10.4.451.3495

Lewin, K. (1939). Patterns of Aggressive Behavior in Experimentally Created Social Climates. Journal of Social Psychology, 10, 271-301.

https://doi.org/10.1080/00224545.1939.9713366

https://tu-dresden.de/mn/psychologie/ipep/lehrlern/ressourcen/dateien/lehre/lehramt/ lehrveranstaltun-

gen/Lehrer_Schueler_Interaktion_SS_2011/Lewin_1939_original.pdf?lang=en

Lingard, B., \& Christie, P. (2003). Leading Theory: Bourdieu and the Field of Educational Leadership. An Introduction and Overview to This Special Issue. International Journal of Leadership in Education, 6, 317-333. https://doi.org/10.1080/1360312032000150724

Male, T., \& Palaiologou, I. (2012). Learning-Centred Leadership or Pedagogical Leader- 
ship? An Alternative Approach to Leadership in Education Contexts. International Journal of Leadership in Education Theory and Practice, 15, 107-118. https://doi.org/10.1080/13603124.2011.617839

Merriam, S. B. (2009). Qualitative Research: A Guide to Design and Implementation. San Francisco: Jossey Bass.

Mulford, B. (2008). The Leadership Challenge: Improving Learning in Schools (pp. 1-78). Camberwell: Australian Council for Educational Research. https://research.acer.edu.au/aer/2

Santamaría, L. J. (2016). Theories of Educational Leadership. Oxford Bibliographies, Oxford: Oxford University Press. https://doi.org/10.1093/obo/9780199756810-0153

Sergiovanni, T. J. (1992). Moral Leadership: Getting to the Heart of School Improvement. New York: Jossey-Bass Inc.

Shafa, M. D. (2010). Challenges of School Improvement: A Study of a Headteacher from the Northern Areas of Pakistan. In J. A. Khaki, \& Q. Safdar (Eds.), Educational Leadership in Pakistan: Ideals and Realities (pp. 80-103). Karachi: Oxford University Press.

Spring, J. (2008). Research on Globalization and Education. Review of Educational Research, 78, 330-363. https://doi.org/10.3102/0034654308317846

Starratt, R. (2004). Ethical Leadership. San Francisco, CA: Jossey Bass.

Steiner-Khamsi, G., \& Waldow, F. (2012). World Yearbook of Education 2012: Policy Borrowing and Lending. London, New York: Routledge. https://doi.org/10.4324/9780203137628

Tajik, M. A. (2010). Leaders as Agents of Change and Their Change Strategies. In J. A. Khaki, \& Q. Safdar (Eds.), Educational Leadership in Pakistan: Ideals and Realities (pp. 169-192). Karachi: Oxford University Press.

Tarar, A. (2006). Diversionary Incentives and the Bargaining Approach to War. International Studies Quarterly, 50, 169-188. https://doi.org/10.1111/j.1468-2478.2005.00397.x

Tikly, L. (2010). Globalisation and Education in the Postcolonial World: Towards a Conceptual Framework. Comparative Education, 33, 151-171.

https://doi.org/10.1080/03050060124481

Yin, R. K. (2006). Case Study Research: Design and Methods (p. 25). Applied Social Research Methods Series, Vol. 5, Thousand Oaks, CA, London: Sage Publications. 